\title{
ANALISIS KEBUTUHAN PARKIR
}

\section{BANK MEGA KOTA PALOPO}

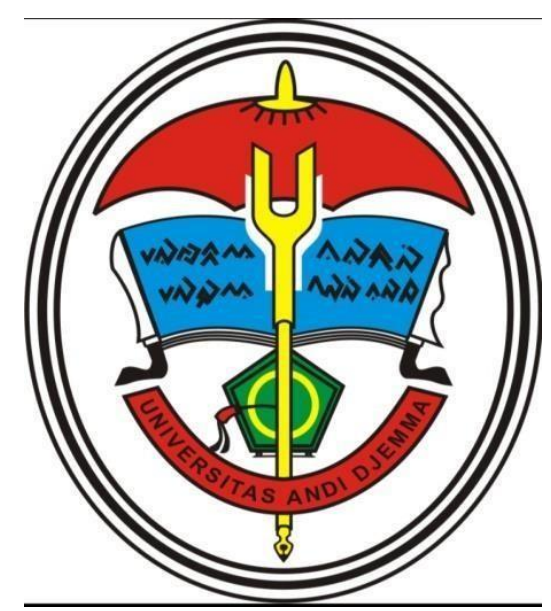

DI SUSUN OLEH :

INDRA YHOGA PRATAMA (18.023.22.201.117)

YOUGI YUSMAN

(18.023.22.201.122)

AFRA WULANDARI

(21.023.22.201.202)

FAKULTAS TEKNIK

PROGRAM STUDI TEKNIK SIPIL

UNIVERSITAS ANDI DJEMMA PALOPO

2021/2022 


\section{KATA PENGANTAR}

Dengan menyebut nama Allah SWT yang Maha Pengasih lagi Maha Panyayang, Kami panjatkan puja dan puji syukur atas kehadirat-Nya, yang telah melimpahkan rahmat, hidayah, dan inayah-Nya kepada kami, sehingga kami bisa selesaikan makalah TENTANG TERMINAL DAN PERPARKIRAN. Terlepas dari semua itu, Kami menyadari seutuhnya bahwa masih jauh dari kata sempurna baik dari segi susunan kalimat maupun tata bahasanya. Oleh karena itu, kami terbuka untuk menerima segala masukan dan kritik yang bersifat membangun dari pembaca sehingga kami bisa melakukan perbaikan makalah ini sehingga menjadi makalah yang baik dan benar. Akhir kata kami meminta semoga makalah tentang terminal, memberikan manfaat ataupun inpirasi pada pembaca. 


\begin{abstract}
ABSTRAK
Paper ini membahas bagaimana kebutuhan parkir di Bank Mega Kota Palopo berdasarkan survei parkir yang telah dilakukan. Survei dilakukan selama 4 hari dengan mengakomodir hari kerja dan hari libur. Paper ini merupakan tugas mata kuliah perencanaan terminal dan perparkiran.
\end{abstract}




\section{BAB I \\ PENDAHULUAN}

A. LATAR BELAKANG

Kendaraan angkutan umum dalam suatu wilayah. Terminal juga merupakan sarana angkutan yang ramai sekali dengan kegiatan-kegiatan masyarakat.Terminal adalah prasarana transportasi jalan untuk keperluanmemuat dan menurunkan barang, serta mengatur kedatangan dan keberangkatan di umum. Keberadaan terminal berperan dalam menentukan tingkat kinerja dari pelayanan alamnya,maka sudah menjadi kebiasaan seperti, kemacetan, kepadatan kendaraan, ketidak tertiban lalu lintas khususnya kendaraan berjenis angkutan kota atau angkot masyarakat menyebutnya. Angkutan kota atau angkot adalah sebuah moda transportasi perkotaan yang merujuk kepada kendaraan umum dengan rute yang sudah ditentukan, tidak seperti bus yang mempunyai halte sebagai tempat dan peraturan yang berlaku di kawasan terminal, sehingga menambah kemacetan dan kepadatan kendaraan di kawasan tersebut akibat angkutan kota yang tidak disiplin. Apalagi pada saat jam-jam tertentu seperti jam masuk kerja, dan pulang kerja, jalanan akan sangat padat dan macet di tambah angkutan kota yang tidak tertib. perhentian yang sudah ditentukan, sama halnya dengan angkutan umum atau angkutan kota khususnya di kawasan terminal angkutan kota Leuwi Panjang, beberapa angkutan kota yang tidak patuh akan tata tertib.

Perparkiran adalah salah satu masalah yang sering sekali dijumpai dalam hal transportasi, terutama dalam penyebab kemacetan yang sedang merajalela di berbagai kota besar yang sedang berkembang, begitupun Indonesia. Perparkiran menjadi fenomena yang mempengaruhi pergerakan kendaraan disaat kendaraan-kendaraan yang mempunyai intensitas pergerakan yang begitu tinggi akan terhambat oleh kendaraan yang parkir dibahu jalan sehingga menyebabkan kemacetan. Pada umumnya kendaraan yang parkir di pinggir jalan berada di sekitar tempat atau pusat kegiatan seperti : sekolah, kantor, pasar swalayan, pasar tradisional, rumah makan, dan lain-lain. Usaha 
yang perlu dilakukan untuk menangani masalah perparkiran tersebut, diperlukan pengadaan lahan parkir yang cukup memadai dan pembentukan model lahan parkir yang tepat pada lahan parkir yang tersedia, mengingat kebutuhan akan lahan parkir (demand) dan prasarana yang dibutuhkan (supply) harus seimbang dengan karakteristik perparkiran. Parkir semestinya hanya digunakan untuk memberhentikan kendaraan untuk sementara, tidak dalam waktu lama atau bahkan berhari - hari yang dilakukan.Penggunaan parkir sesuai peraturan yang rapi akan

memudahkan petugas parkir dalam memarkirkan kendaraan. Dapat digaris bawahi bahwa kegiatan parkir tersebut seharusnya tidak mengganggu pergerakan ruang lalu lintas dan juga tidak mengganggu pejalan kaki, tapi pada kenyataannya

Perparkiran yang selama ini berlangsung terutama on street parking sering menghambat pergerakan lalu lintas, sehingga terjadilah kemacetan. Hal ini dikarenakan pemakaian lahan parkir yang tidak seharusnya. Contoh dari pemakaian lahan parkir yang tidak seharusnya adalah karena kendaraan parkir yang tidak diparkirkan dengan benar,kendaraan tidak diparkirkan sesuai dengan posisi parkiryang sudah ditandai dengan marka parkir.

\section{B. RUMUSAN MASALAH}

Bagaimanakah dampak penggunaan parkir badan jalan (on street parking) diBANK MEGA PALOPO ?

\section{TUJUAN}

1. Untuk mengetahui apa itu terminal danperparkiran dalam kehiduapan sehari -hari?

2. Untuk mengetahui seberapa pentingkah terminal dan perparkiran yang ada disetiap kota maupun desa.

3. Menjadikan terminal dan perparkiran sarana agar lalu lintas dapat berjalan denganbaik dan semestinya. 


\section{BAB II \\ LANDASAN TEORI}

\section{A. PENGERTIAN TERMINAL}

Terminal adalah salah satu komponen dari sistem transportasi yang mempunyai fungsi utama sebagai tempat pemberhentian sementara kendaraan umum untuk menaikkan da menurunkan penumpang dan barang hingga sampai ketujuan akhir suatu perjalanan, juga sebagai tempat pengendalian, pengawasan, pengaturan dan pengoperasian sistem arus angkuta penumpang dan barang, disamping itu juga berfungsi untuk melancarkan arus angkutan penumpang atau barang (Departemen Perhubungan, 1996). Menurut Peraturan Pemerintah Republik Indonesia Nomor 79 Tahun 2013 Tentang Jaringan Lalu Lintas dan Angkutan Jalan, terminal adalah pangkalan kendaraan bermotor umum yang digunakan untuk mengatur kedatangan dan keberangkatan, menaikkan dan menurunkan orang dan atau barang, serta perpindahan moda angkutan. Terminal terdiri dari 2 (dua) jenis yaitu berupa:

1. Terminal penumpang,

2. Terminal barang.

\section{FUNGSI TERMINAL}

Terminal penumpang berfungsi untuk mengatur kedatangan dan keberangkatan, menaikkan dan menurunkan orang, serta perpindahan moda angkutan yang terpadu dan pengawasan angkutan. Terminal penumpang menurut pelayanannya dikelompokan dalam 3 (tiga) tipe yaituberupa:

a. Terminal penumpang tipe A,

b. Terminal penumpang tipe $\mathrm{B}$

c. Terminal penumpang tipe $\mathrm{C}$.

Menurut Departemen Perhubungan (1996), fungsi terminal pada dasarnya dapatdilihat dari 3 (tiga) unsur terkait terminal, yaitu berupa:

1. Penumpang

Fungsi terminal bagi penumpang adalah untuk kenyamanan menunggu, kenyamanan perpindahan dari satu moda atau kendaraan ke moda yang lain, tempat tersedianya fasilitas-fasilitas dan informasi (pelataran, teluk, ruang tunggu, papan informasi, 
toilet,kios-kios, loket, fasilitas parkir dari kendaraan pribadi dan lain-lain).

\section{Pemerintah}

Fungsi terminal bagi pemerintah adalah dari segi perencanaan dan manajemen lalu lintas, untuk menata lalu lintas dan menghindari kemacetan, sebagai sumber pemungutan retribusi dan sebagai pengendali arus angkutan umum.

\section{Operator Angkutan Umum}

Fungsi terminal bagi operator angkutan umum adalah untuk pengaturan pelayanan operasi angkutan umum, penyediaan fasilitas istirahat dan informasi bagi awak angkutan umum dan fasilitas pangkalan.

Menurut Departemen Perhubungan (1996), terminal dapat dibedakan berdasarkan jenis angkutan yang digunakan, yaitu berupa:

1. Terminal Penumpang

Terminal penumpang adalah terminal untuk menaikkan dan atau menurunkan penumpang.

\section{Terminal Barang/Cargo}

Terminal barang/cargo adalah terminal untuk perpindahan (bongkar muat) barang darimoda transport yang satu ke moda transport yang lainnya.

\section{Terminal Khusus}

Terminal khusus adalah terminal yang dipengaruhi oleh sifat-sifat barang yang diangkut.

\section{Terminal Truk}

Terminal truk adalah terminal yang sesuai dengan kebutuhannya, dinyatakan denganjumlah truk yang dapat diparkir atau menunggu dalam satuan waktu.

\section{Kebutuhan Fasilitas-Fasilitas Terminal}

Adapun kebutuhan luas fasilitas dalam terminal angkutan umum berdasarkan Departemen Perhubungan (1996) dapat dilihat pada Tabel 2.1.

Kebutuhan luas fasilitas dalam terminal Angkutan umum tipe A

\begin{tabular}{|c|c|c|}
\hline NO & Jenis fasilitas & Tipe A (m persegi ) \\
\hline 1 & Ruang parkir AKAP & 1.120 \\
\hline 2 & Ruang parkir AKDP & 540 \\
\hline 3 & Ruang parkir Angkutan kota & 800 \\
\hline 4 & Ruang parkir Angkutan desa & 900 \\
\hline 5 & Ruang parkir Angkutan Pribadi & 600 \\
\hline 6 & Ruang servis & 500 \\
\hline
\end{tabular}




\begin{tabular}{|c|c|c|}
\hline 7 & Pompa bensin & 500 \\
\hline 8 & Sirkulasi kendaraan & 1.960 \\
\hline 9 & Bengkel & 150 \\
\hline 10 & Ruang istirahat & 50 \\
\hline 11 & Gedung & 25 \\
\hline 12 & Ruang parkir cadangan & 1.980 \\
\hline 13 & Ruang tunggu & 2.625 \\
\hline 14 & Sirkulasi orang & 1.050 \\
\hline 15 & Kamar mandi & 72 \\
\hline 16 & Kios & 1.575 \\
\hline 17 & Mushollah & 72 \\
\hline 18 & Ruang administrasi & 78 \\
\hline
\end{tabular}




\begin{tabular}{|c|c|c|}
\hline 19 & Ruang pengawas & 23 \\
\hline 20 & Loket & 3 \\
\hline 21 & Peron & 4 \\
\hline 22 & Retribusi & 6 \\
\hline 23 & Ruang informasi & 12 \\
\hline 24 & Ruang P3K & 45 \\
\hline 25 & Ruang perkantoran & 150 \\
\hline 26 & Ruang luar penghijaun & 6.653 \\
\hline
\end{tabular}

Klasifikasi Terminal Berdasarkan Tingkat Pelayanan Ada 3 (tiga) jenis terminal dapat dibedakan berdasarkan tingkat pelayanannya, yaitu berupa:

a. Terminal utama yaitu 50-100 kendaraan/jam,

b. Terminal madya yaitu $25-50$ kendaraan/jam,

c. Terminal cabang yaitu $<25$ kendaraan/jam.

Menurut Keputusan Menteri Perhubungan Nomor 31 Tahun 1995 Tentang

Terminal Transportasi Jalan, terminal penumpang terdiri dari 2 (dua) jenis tipe yaitu berupa:

1. Terminal Penumpang Tipe A

Terminal penumpang tipe A melayani kendaraan umum untuk Angkutan Antar Kota Antar Provinsi (AKAP) dan atau Angkutan Lintas Batas Negara, Angkutan Antar Kota Dalam Provinsi (AKDP), Angkutan Kota dan Angkutan Perdesaan.

2. Terminal Penumpang Tipe B

penumpang tipe B berfungsi melayani kendaraan umum Angkutan Kota Dalam Provinsi (AKDP), Angkutan Kota dan Angkutan Perdesaan.

3. Terminal Penumpang Tipe $\mathrm{C}$

Terminal penumpang tipe $\mathrm{C}$ berfungsi melayani kendaraan umum untuk Angkutan Kota dan Angkutan Perdesaan. 


\section{B.PERPARKIRAN}

\section{PENGERTIAN}

Parkir adalah lalu lintas berhenti yang ditinggal pengemudi saat mencapaisuatu tempat tujuan dengan jangka waktu tertentu. Perilaku pengendara kendaraan bermotor memiliki kecenderungan untuk memarkir kendaraannya tidak jauhdengan tempat kegiatannya.

Menurut Direktorat Jenderal Perhubungan Darat (1998), ada beberapapengertian tentang perparkiran bahwa :

1. Parkir adalah keadaan tidak bergerak suatu kendaraan yang tidak bersifat sementara

2. Berhenti adalah keadaan tidak bergerak suatu kendaraan untuk sementara dengan pengemudi tidak meninggalkan kendaraan

3. Fasilitas parkir adalah lokasi yang ditentukan sebagai tempatpemberhentian kendaraan yang tidak bersifat sementara untuk melakukan kegiatan pada suatu kurun waktu tertentu

4. Fasilitas parkir di badan jalan (on-street parking) adalah fasilitas parkir yang menggunakan tepi jalan

5. Fasilitas parkir di luar badan jalan ( off-street parking) adalah fasilitas parkir kendaraan di luar tepi jalan umum yang dibuat khusus atau penunjang kegiatan yang dapat berupa tempat parkir atau gedung parkir.

\section{FASILITAS PARKIR}

Menurut Joseph Dechiara \& Lee Koppelmen, 1975 (dalam Ririh Sudiraharjo), fasilitas parkir dan jenis parkir menurut penempatannya, yaitu :

a. Parkir di tepi jalan (on street parking)

Parkir di tepi jalan adalah parkir yang mengambil tempat di sepanjang jalan dengan atau tanpa melebarkan jalan untuk pembatas parkir. Jenis parkir ini baik untuk pengunjung yang ingin dekat dengan tempat tujuannya.

b. Parkir tidak di tepi jalan (off street parking)

Cara ini menempati pelataran tertentu di luar badan jalan baik di halamanterbuka atau dalam bangunan khusus untuk parkir dan mempunyai pintu 
pelayanan masuk untuk mengambil karcis parkir sehingga dapat diketahuijumlah kendaraan yang parkir dan jangka waktu kendaraan parkir.

Adapun pengaruh besaran ruang parkir adalah sebagai berikut :

1. Ruang bebas kendaraan parkir

Untuk sepeda motor, biasanya ruang bebas arah samping diambil $2 \mathrm{~cm}$ danarah memanjang $20 \mathrm{~cm}$.

2. Lebar bukaan pintu kendaraan

Ukuran lebar bukaan pintu merupakan fungsi karakteristik pemakai kendaraan yang memanfaatkan fasilitas parkir. Karakteristik pengguna kendaraan yang memanfaatkan fasilitas parkir dibagi menjadi tiga seperti yang ditunjukkan pada table dibawah ini.

\section{Tabel lebar bukaan pintu kendaraan}

\begin{tabular}{|l|l|c|}
\hline Jenis bukaan pintu & $\begin{array}{l}\text { Pengguna dan atau } \\
\text { Peruntukan fasilitas } \\
\text { parker }\end{array}$ & Golongan \\
\hline $\begin{array}{l}\text { Pintu depan/belakang } \\
\text { Terbuka tahap awal 55 } \\
\mathrm{cm}\end{array}$ & $\begin{array}{l}\text { Karyawan/ pekerja Kantor } \\
\text { tamu/pengunjung } \\
\text { Pusat kegiatan perkantoran } \\
\text { Perdagangan,eceran rumah } \\
\text { Sakit,bioskop }\end{array}$ & I \\
\hline $\begin{array}{l}\text { Pintu depan/belakang } \\
\text { Terbuka penuh 75 cm }\end{array}$ & $\begin{array}{l}\text { Pengunjung tempat olahraga, } \\
\text { Pusat hiburan rekreasi,hotel, } \\
\text { Pusat perdagangan eceran } \\
\text { Swalayan,rumah sakit,bioskop. }\end{array}$ & II \\
\hline $\begin{array}{l}\text { Pintu depan terbuka } \\
\text { Penuh dan ditambah } \\
\text { Kursi roda }\end{array}$ & Orang cacat & III \\
\hline
\end{tabular}


1. Penentuan satuan ruang parkir (SRP)

Berdasarkan Tabel 3.1 penentuan Satuan Ruang Parkir (SRP) dibagi atas tiga jenis kendaraan dan berdasarkan penentuan SRP untuk mobil penumpang diklassifikasikan menjadi tiga golongan, seperti Tabel 3.2.

Tabel Penentuan Satuan Ruang Parkir

\begin{tabular}{|c|c|}
\hline Jenis kendaraan & $\begin{array}{l}\text { SRP (m } \\
\text { persegi ) }\end{array}$ \\
\hline $\begin{array}{l}\text { 1.a. mobil penumpang untuk } \\
\text { Golongan I }\end{array}$ & $2.3 \times 5.0$ \\
\hline $\begin{array}{l}\text { b. Mobil penumpang untuk } \\
\text { golongan II }\end{array}$ & $2.5 \times 5.0$ \\
\hline $\begin{array}{l}\text { c. Mobil penumpang untuk } \\
\text { golongan III }\end{array}$ & $3.0 \times 5.0$ \\
\hline 2.Bus atau truk & $3.4 \times 12.5$ \\
\hline 3.Sepeda motor & $0.75 \times 2.0$ \\
\hline
\end{tabular}

Standar Kebutuhan Ruang Parkir :

Standar kebutuhan luas area kegiatan parkir berbeda antara satu dengan yang lain tergantung pada beberapa hal antara lain pelayanan, tarif yang

diberlakukan, ketersediaan ruang parkir, tingkat pemilikan kendaraan bermotor, tingkat pendapatan masyarakat. Be rdasarkan hasil studi Direktorat Jenderal 17 Perhubungan Darat, kegiatan dan standar -standar kebutuhan parkir adalah sebagai berikut :

Kegiatan parkir tetap :

Kegiatan parkir tetap meliputi $\mathrm{p}$ usat perdagangan, pusat perkantoran swasta atau pemerintahan, sekolah/perguruan tinggi, hotel dan tempat penginapan, rumah sakit, pasar swalayan atau pusat perdagangan eceran, dan tempat rekreasi. Kecenderungan kegiatan parkir tetap pada Kawasan Malioboro adalah pasar swalayan atau pusat perdagangan eceran dan tempat rekreasi.

1. Pasar swalayan atau pusat perdangangan eceran

\begin{tabular}{|l|c|c|c|c|c|c|c|c|c|}
\hline $\begin{array}{l}\text { Luas area } \\
\text { total } 100 \mathrm{~m}\end{array}$ & 50 & 75 & 100 & 150 & 200 & 300 & 400 & 500 & 1000 \\
\hline $\begin{array}{l}\text { Kebutuhan } \\
\text { (srp) }\end{array}$ & 225 & 250 & 270 & 310 & 350 & 440 & 520 & 600 & 1050 \\
\hline
\end{tabular}


2. Tempat rekreasi

\begin{tabular}{|l|l|l|l|l|l|l|l|l|l|}
\hline $\begin{array}{l}\text { Luas area } \\
\text { total } 100 \mathrm{~m}\end{array}$ & 50 & 100 & 150 & 200 & 400 & 800 & 1600 & 3200 & 6400 \\
\hline $\begin{array}{l}\text { Kebutuhan } \\
(\mathrm{SRP})\end{array}$ & 103 & 109 & 115 & 122 & 146 & 196 & 295 & 494 & 892 \\
\hline
\end{tabular}

Kegiatan Parkir yang Bersifat Sementara :

Kegiatan parkir bersifat sementara yang durasi parkirnya 1,5 sampai 2 jam saja yang meliputi bioskop/gedung pertunjukan, tempat pertandingan olahraga.

Kebutuhan ruang parkir dapat dilihat pada tabel.

\begin{tabular}{|c|c|c|}
\hline peruntukan & $\begin{array}{c}\text { Satuan(SRP untuk mobil } \\
\text { Penumpang) }\end{array}$ & $\begin{array}{l}\text { Kebutuhan ruang } \\
\text { parkir }\end{array}$ \\
\hline $\begin{array}{l}\text { Pusat perdangan } \\
\text { - Pertokohan } \\
\text { - Pasar swalayan } \\
\text { - pasar }\end{array}$ & $\begin{array}{l}\text { SRP / } 100 \text { m luas lantai } \\
\text { Efektif } \\
\text { SRP / } 100 \text { m luas lantai } \\
\text { Efektif } \\
\text { SRP / } 100 \text { m luas lantai } \\
\text { Efektif }\end{array}$ & $\begin{array}{l}3,5-7,5 \\
3,5-7,5 \\
3,5-7,5\end{array}$ \\
\hline $\begin{array}{l}\text { Pusat perkantoran } \\
\text { - } \\
\text { pelayanan } \\
\text { bukan umum } \\
\text { - } \\
\text { pelayanan umum }\end{array}$ & $\begin{array}{l}\text { SRP / } 100 \text { m luas lantai } \\
\text { Efektif } \\
\text { SRP / } 100 \text { m luas lantai } \\
\text { Efektif }\end{array}$ & $\begin{array}{l}1,5-3,5 \\
1,5-3,5\end{array}$ \\
\hline $\begin{array}{l}\text { Sekolah } \\
\text { Hotel/tempat } \\
\text { penginapan dan rumah sakit }\end{array}$ & $\begin{array}{l}\text { SRP/mahasiswa } \\
\text { SRP / kamar }\end{array}$ & $\begin{array}{l}0,7-1,0 \\
0,2-1,0\end{array}$ \\
\hline $\begin{array}{l}\text { Bioskop/gedung } \\
\text { pertunjukan }\end{array}$ & $\begin{array}{l}\text { SRP / tempat tidur } \\
\text { SRP / tempat duduk }\end{array}$ & $\begin{array}{l}0,2-1,3 \\
0,2-0,4\end{array}$ \\
\hline
\end{tabular}

Pada perencanaan terminal dan lokasi parkir yang baik adalah yang perencanaan laokasinya secara sistem jaringan mampu berperan dalam melancarkan pergerakan sistem transportsi secara keseluruhan, dengan demikian perencanaan dan pengembangannya perlu di tata dalam satu kesatuan sistem yang terpadu (Fisu, 2018). Perencanaan sistem angkutan yang dibuat tnpa pertimbangan matang akan berdampak pada pola pergerakan, arus lalu lintas perkotaan, bahkan hingga menyebabkan kecelakaan lalu lintas (Fisu, 2019). 
BAB III

\section{PEMBAHASAN}

1. LOKASI PENGAMATAN ( BANK MEGA PALOPO )
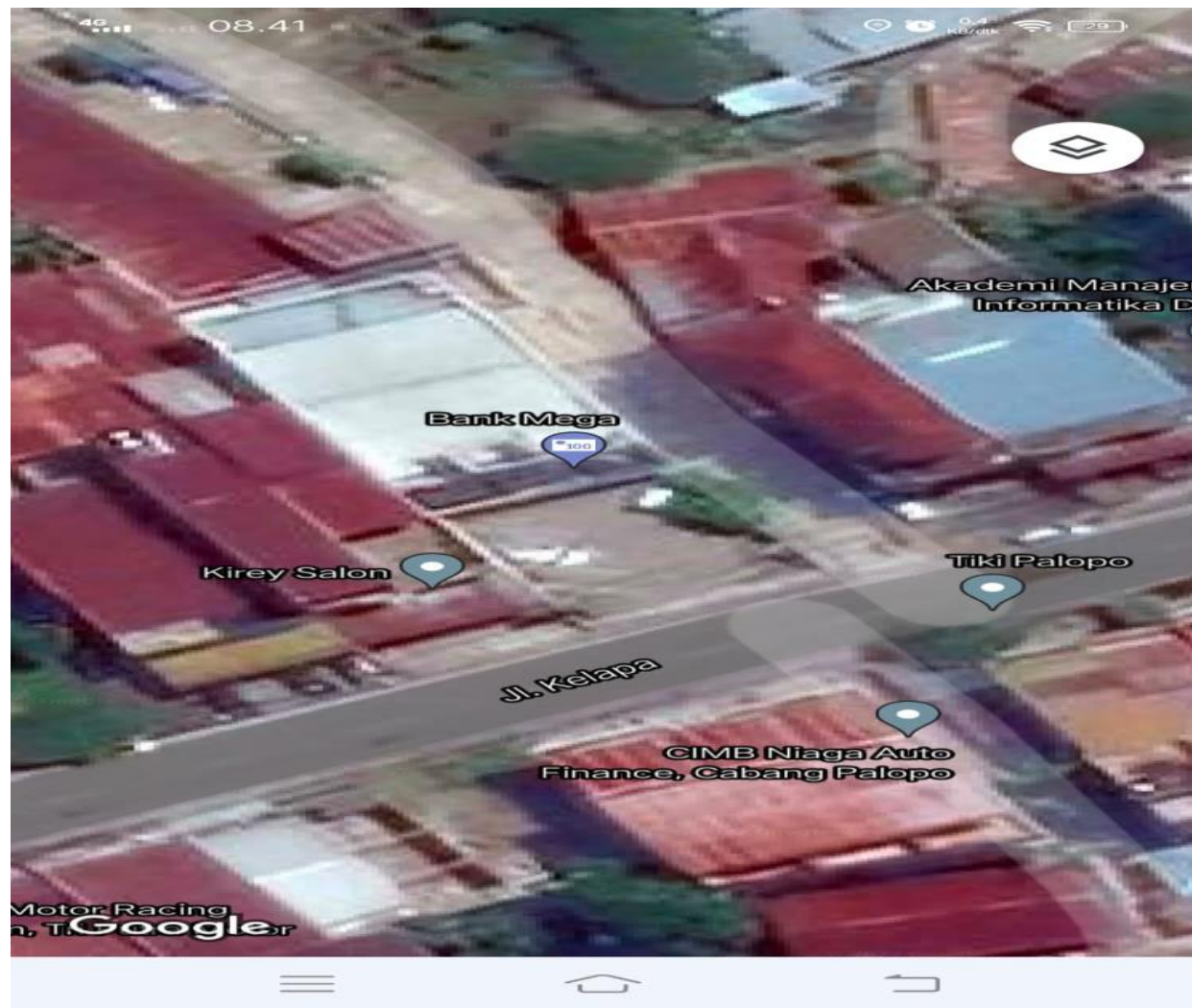
2. KONDISI PARKIRAN ( BANK BRI KENCANA PALOPO )
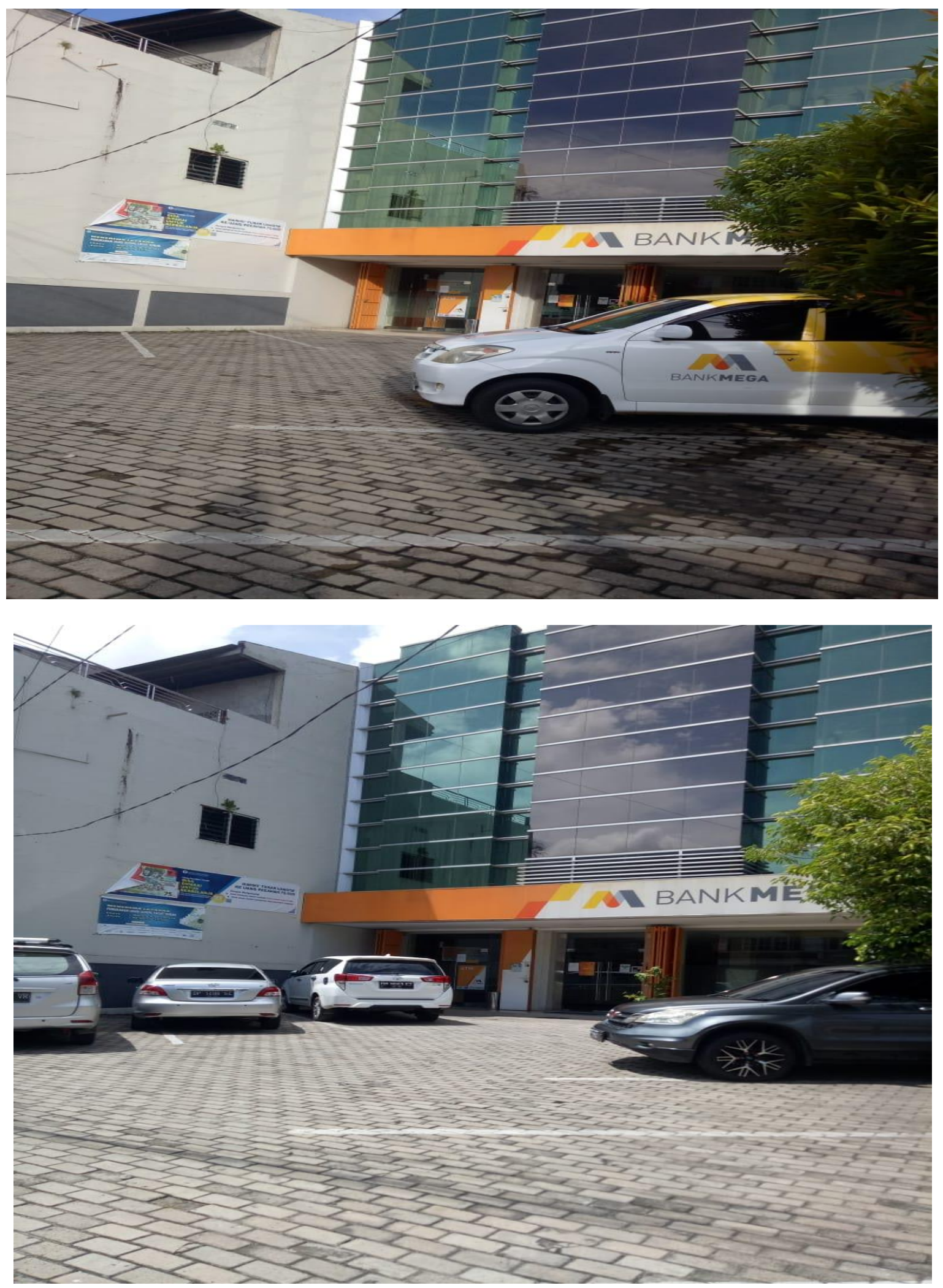
DOCUMENTASI PENGAMBILAN DATA SURVEY KENDARAAN

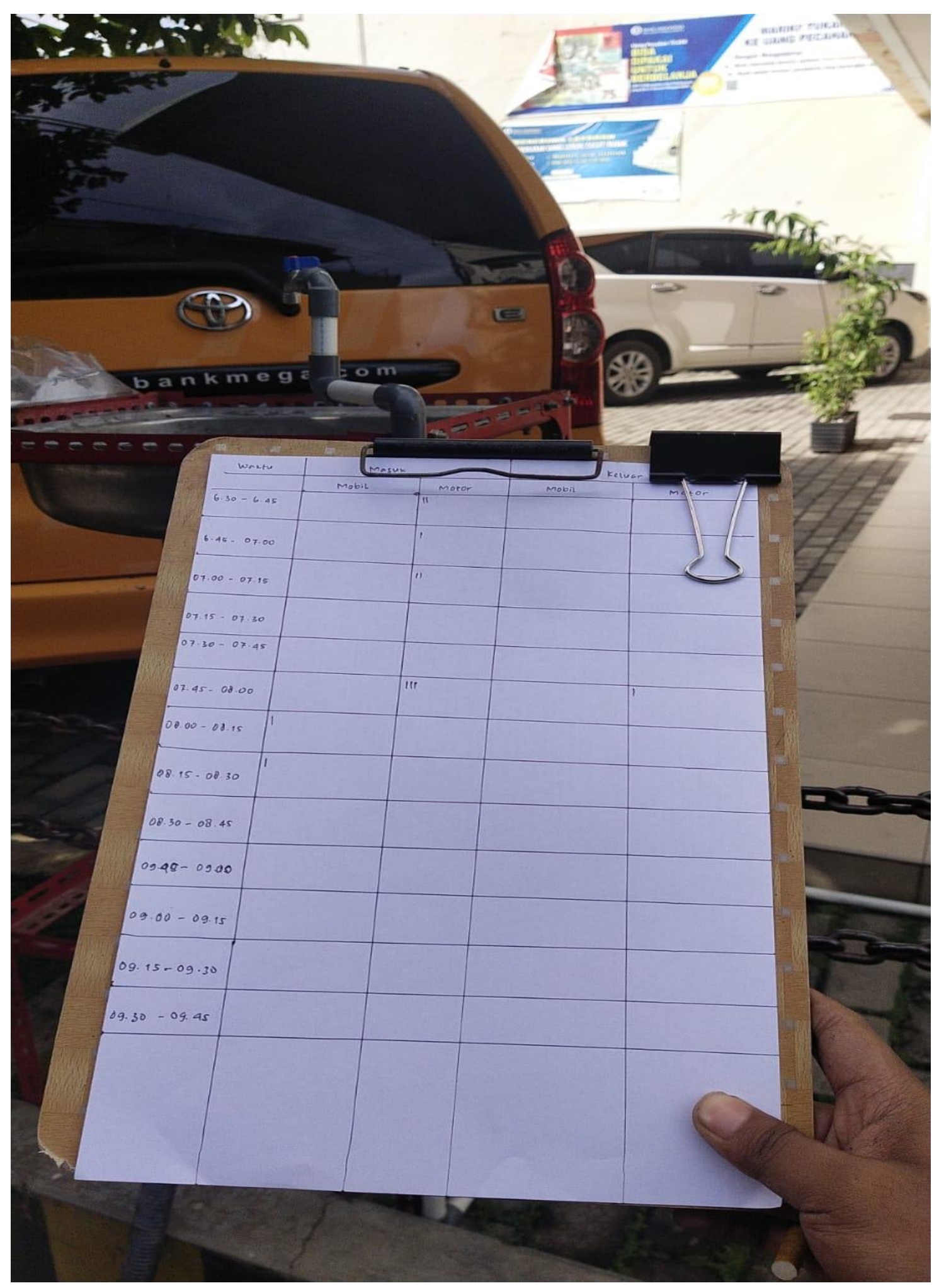




\section{HASIL SURVEY SELAMA 4 HARI}

TANGGAL

LOKASI PARKIR
18 Januari 2022

PARKIRAN BANK MEGA

\begin{tabular}{|c|c|c|c|c|c|}
\hline \multirow{2}{*}{ NO } & \multirow{2}{*}{ WAKTU } & \multicolumn{2}{|c|}{ MASUK } & \multicolumn{2}{|c|}{ KELUAR } \\
\hline & & MOTOR & MOBIL & MOTOR & MOBIL \\
\hline 1 & $08.30-08.45$ & & & & \\
\hline 2 & $08.45-09.00$ & 3 & & 2 & \\
\hline 3 & $09.00-09.15$ & & & & \\
\hline 4 & $09.15-09.30$ & & & & \\
\hline 5 & $09.30-09.45$ & 2 & & 2 & \\
\hline 6 & $09.45-10.00$ & 2 & & 1 & \\
\hline 7 & $10.00-10.15$ & 2 & 1 & 2 & \\
\hline 8 & $10.15-10.30$ & 2 & & 2 & \\
\hline 9 & $10.30-10.45$ & & 1 & & 1 \\
\hline 10 & $10.45-11.00$ & & 1 & & \\
\hline 11 & $11.00-11.15$ & & 1 & & 1 \\
\hline 12 & $11.15-11.30$ & 1 & & & \\
\hline 13 & $11.30-11.45$ & 1 & & 1 & \\
\hline 14 & $11.45-12.00$ & 1 & & & \\
\hline 15 & $12.00-12.15$ & & & & \\
\hline 16 & $12.15-12.30$ & 1 & & 1 & \\
\hline 17 & $12.30-12.45$ & & 2 & & \\
\hline 18 & $12.45-13.00$ & & & & \\
\hline 19 & $13.00-13.15$ & & 1 & & \\
\hline 20 & $13.15-13.30$ & 3 & & & \\
\hline 21 & $13.30-13.45$ & & & & \\
\hline 22 & $13.45-14.00$ & 1 & 1 & 2 & \\
\hline 23 & $14.00-14.15$ & 2 & & & 2 \\
\hline 24 & $14.15-14.30$ & 1 & & & \\
\hline 25 & $14.30-14.45$ & 1 & & & \\
\hline 26 & $14.45-15.00$ & 2 & & 2 & \\
\hline 27 & $15.00-15.15$ & & & & \\
\hline 28 & $15.15-15.30$ & & & 2 & \\
\hline 29 & $15.30-15.45$ & & & & \\
\hline 30 & $15.45-16.00$ & & & 1 & \\
\hline 31 & $16.00-16.15$ & & & & 1 \\
\hline 32 & $16.15-16.30$ & & & & \\
\hline 33 & $16.30-16.45$ & & & 1 & \\
\hline 34 & $16.45-17.00$ & & & 5 & 1 \\
\hline 35 & $17.00-17.15$ & & & 1 & \\
\hline
\end{tabular}


TANGGAL

LOKASI PARKIR
19 Januari 2022

PARKIRAN BANK MEGA

\begin{tabular}{|c|c|c|c|c|c|}
\hline \multirow{2}{*}{ NO } & \multirow{2}{*}{ WAKTU } & \multicolumn{2}{|c|}{ MASUK } & \multicolumn{2}{|c|}{ KELUAR } \\
\hline & & MOTOR & MOBIL & MOTOR & MOBIL \\
\hline 1 & $08.30-08.45$ & 3 & 1 & & \\
\hline 2 & $08.45-09.00$ & 2 & 1 & 2 & \\
\hline 3 & 09.00-09.15 & 2 & & & \\
\hline 4 & $09.15-09.30$ & 1 & & 1 & \\
\hline 5 & $09.30-09.45$ & 1 & 1 & & \\
\hline 6 & $09.45-10.00$ & 3 & & & 1 \\
\hline 7 & $10.00-10.15$ & & & 1 & \\
\hline 8 & $10.15-10.30$ & 2 & & 2 & \\
\hline 9 & $10.30-10.45$ & 1 & 1 & & \\
\hline 10 & $10.45-11.00$ & 2 & & & \\
\hline 11 & $11.00-11.15$ & 1 & & & \\
\hline 12 & $11.15-11.30$ & 1 & & 1 & \\
\hline 13 & $11.30-11.45$ & & & 1 & \\
\hline 14 & $11.45-12.00$ & 1 & & & \\
\hline 15 & $12.00-12.15$ & & & & \\
\hline 16 & $12.15-12.30$ & & & & \\
\hline 17 & $12.30-12.45$ & & & & \\
\hline 18 & $12.45-13.00$ & 2 & & 1 & 1 \\
\hline 19 & $13.00-13.15$ & 2 & 1 & 1 & \\
\hline 20 & $13.15-13.30$ & 1 & & 1 & 1 \\
\hline 21 & $13.30-13.45$ & 1 & & & \\
\hline 22 & $13.45-14.00$ & & & & \\
\hline 23 & $14.00-14.15$ & & & & \\
\hline 24 & $14.15-14.30$ & 1 & & 2 & \\
\hline 25 & $14.30-14.45$ & & & & \\
\hline 26 & $14.45-15.00$ & & & 1 & \\
\hline 27 & $15.00-15.15$ & & & 1 & \\
\hline 28 & $15.15-15.30$ & 1 & & & \\
\hline 29 & $15.30-15.45$ & & & 1 & \\
\hline 30 & $15.45-16.00$ & & & & \\
\hline 31 & $16.00-16.15$ & & & & \\
\hline 32 & $16.15-16.30$ & & & & \\
\hline 33 & $16.30-16.45$ & 1 & & 4 & \\
\hline 34 & $16.45-17.00$ & & & 1 & 1 \\
\hline 35 & $17.00-17.15$ & & & & \\
\hline
\end{tabular}


TANGGAL

LOKASI PARKIR
20 Januari 2022

PARKIRAN BANK MEGA

\begin{tabular}{|c|c|c|c|c|c|}
\hline \multirow{2}{*}{ NO } & \multirow{2}{*}{ WAKTU } & \multicolumn{2}{|c|}{ MASUK } & \multicolumn{2}{|c|}{ KELUAR } \\
\hline & & MOTOR & MOBIL & MOTOR & MOBIL \\
\hline 1 & $08.30-08.45$ & 4 & & & \\
\hline 2 & $08.45-09.00$ & & 1 & 1 & \\
\hline 3 & $09.00-09.15$ & 1 & & & \\
\hline 4 & $09.15-09.30$ & 1 & & 1 & \\
\hline 5 & $09.30-09.45$ & 2 & & 2 & \\
\hline 6 & $09.45-10.00$ & & & & \\
\hline 7 & $10.00-10.15$ & 2 & & & 1 \\
\hline 8 & $10.15-10.30$ & & 1 & & 1 \\
\hline 9 & $10.30-10.45$ & 1 & 1 & & \\
\hline 10 & $10.45-11.00$ & & & & \\
\hline 11 & $11.00-11.15$ & 1 & 1 & & \\
\hline 12 & $11.15-11.30$ & & & 1 & \\
\hline 13 & $11.30-11.45$ & 1 & & & \\
\hline 14 & $11.45-12.00$ & 1 & & & \\
\hline 15 & $12.00-12.15$ & & & & \\
\hline 16 & $12.15-12.30$ & & & & \\
\hline 17 & $12.30-12.45$ & & & & \\
\hline 18 & $12.45-13.00$ & & & & \\
\hline 19 & $13.00-13.15$ & 2 & 1 & & \\
\hline 20 & $13.15-13.30$ & & & & \\
\hline 21 & $13.30-13.45$ & 1 & & 1 & 1 \\
\hline 22 & $13.45-14.00$ & & & & \\
\hline 23 & $14.00-14.15$ & 1 & & & \\
\hline 24 & $14.15-14.30$ & 1 & & 2 & \\
\hline 25 & $14.30-14.45$ & & & & \\
\hline 26 & $14.45-15.00$ & 2 & 1 & & \\
\hline 27 & $15.00-15.15$ & & & & 1 \\
\hline 28 & $15.15-15.30$ & 1 & & 1 & \\
\hline 29 & $15.30-15.45$ & 1 & & & \\
\hline 30 & $15.45-16.00$ & 2 & & 1 & \\
\hline 31 & $16.00-16.15$ & 1 & & & \\
\hline 32 & $16.15-16.30$ & & & & \\
\hline 33 & $16.30-16.45$ & & & 2 & \\
\hline 34 & $16.45-17.00$ & & & 3 & \\
\hline 35 & $17.00-17.15$ & & & 1 & \\
\hline
\end{tabular}


TANGGAL

LOKASI PARKIR
21 Januari

2022

PARKIRAN BANK MEGA

\begin{tabular}{|c|c|c|c|c|c|}
\hline \multirow{2}{*}{ NO } & \multirow{2}{*}{ WAKTU } & \multicolumn{2}{|c|}{ MASUK } & \multicolumn{2}{|c|}{ KELUAR } \\
\hline & & MOTOR & MOBIL & MOTOR & MOBIL \\
\hline 1 & 08.30-08.45 & 4 & 1 & & \\
\hline 2 & $08.45-09.00$ & 1 & 1 & & \\
\hline 3 & $09.00-09.15$ & 1 & & 1 & 1 \\
\hline 4 & $09.15-09.30$ & 1 & & & \\
\hline 5 & $09.30-09.45$ & & & & \\
\hline 6 & $09.45-10.00$ & 2 & & 1 & \\
\hline 7 & $10.00-10.15$ & & & 2 & \\
\hline 8 & $10.15-10.30$ & 1 & 1 & & \\
\hline 9 & $10.30-10.45$ & 2 & 1 & 1 & \\
\hline 10 & $10.45-11.00$ & & & & 1 \\
\hline 11 & $11.00-11.15$ & 1 & & & \\
\hline 12 & $11.15-11.30$ & & & & \\
\hline 13 & $11.30-11.45$ & 1 & & 2 & \\
\hline 14 & $11.45-12.00$ & 1 & & & \\
\hline 15 & $12.00-12.15$ & & & & \\
\hline 16 & $12.15-12.30$ & & & & \\
\hline 17 & $12.30-12.45$ & & & & \\
\hline 18 & $12.45-13.00$ & 1 & & & \\
\hline 19 & $13.00-13.15$ & 2 & 1 & & \\
\hline 20 & $13.15-13.30$ & & & & \\
\hline 21 & $13.30-13.45$ & & & 2 & \\
\hline 22 & $13.45-14.00$ & 1 & & & \\
\hline 23 & $14.00-14.15$ & & & & \\
\hline 24 & $14.15-14.30$ & 1 & & 2 & \\
\hline 25 & $14.30-14.45$ & & & & 1 \\
\hline 26 & $14.45-15.00$ & 2 & & 2 & \\
\hline 27 & $15.00-15.15$ & & & & \\
\hline 28 & $15.15-15.30$ & 1 & & & \\
\hline 29 & $15.30-15.45$ & 1 & & & \\
\hline 30 & $15.45-16.00$ & & & & \\
\hline 31 & $16.00-16.15$ & 2 & & 2 & \\
\hline 32 & $16.15-16.30$ & & & & \\
\hline 33 & $16.30-16.45$ & & & & \\
\hline 34 & $16.45-17.00$ & & & 4 & \\
\hline 35 & $17.00-17.15$ & & & & 1 \\
\hline
\end{tabular}


HASIL SURVEY / 1 JAM

\begin{tabular}{|c|c|c|c|c|}
\hline \multicolumn{5}{|c|}{ HARI PERTAMA } \\
\hline \multirow{2}{*}{ WAKTU } & \multicolumn{3}{|c|}{ 18 JANUARI 2022 } \\
\cline { 2 - 5 } & MOTOR & MOBIL & MOTOR & MOBIL \\
\hline & 3 & 0 & 2 & 0 \\
\hline $08.00-09.00$ & 3 & 0 & 3 & 0 \\
\hline $09.00-10.00$ & 4 & 3 & 4 & 1 \\
\hline $10.00-11.00$ & 4 & 1 & 1 & 0 \\
\hline $11.00-12.00$ & 3 & 2 & 1 & 0 \\
\hline $12.00-13.00$ & 1 & 2 & 2 & 0 \\
\hline $13.00-14.00$ & 4 & 1 & 2 & 0 \\
\hline $14.00-15.00$ & 6 & 0 & 3 & 0 \\
\hline $15.00-16.00$ & 0 & 0 & 7 & 2 \\
\hline $16.00-17.00$ & 0 & & & \\
\hline
\end{tabular}

HARI KEDUA

19 JANUARI 2022

\begin{tabular}{|c|c|c|c|c|}
\hline \multirow{2}{*}{ WAKTU } & \multicolumn{2}{|c|}{ MASUK } & \multicolumn{2}{c|}{ KELUAR } \\
\cline { 2 - 5 } & MOTOR & MOBIL & MOTOR & MOBIL \\
\hline $08.00-09.00$ & 5 & 2 & 2 & 0 \\
\hline $09.00-10.00$ & 7 & 1 & 0 & 1 \\
\hline $10.00-11.00$ & 5 & 1 & 3 & 0 \\
\hline $11.00-12.00$ & 3 & 0 & 2 & 0 \\
\hline $12.00-13.00$ & 2 & 0 & 1 & 1 \\
\hline $13.00-14.00$ & 4 & 1 & 2 & 2 \\
\hline $14.00-15.00$ & 1 & 0 & 3 & 0 \\
\hline $15.00-16.00$ & 1 & 0 & 2 & 0 \\
\hline $16.00-17.00$ & 1 & 0 & 5 & 1 \\
\hline
\end{tabular}


HASIL SURVEY / 1 JAM

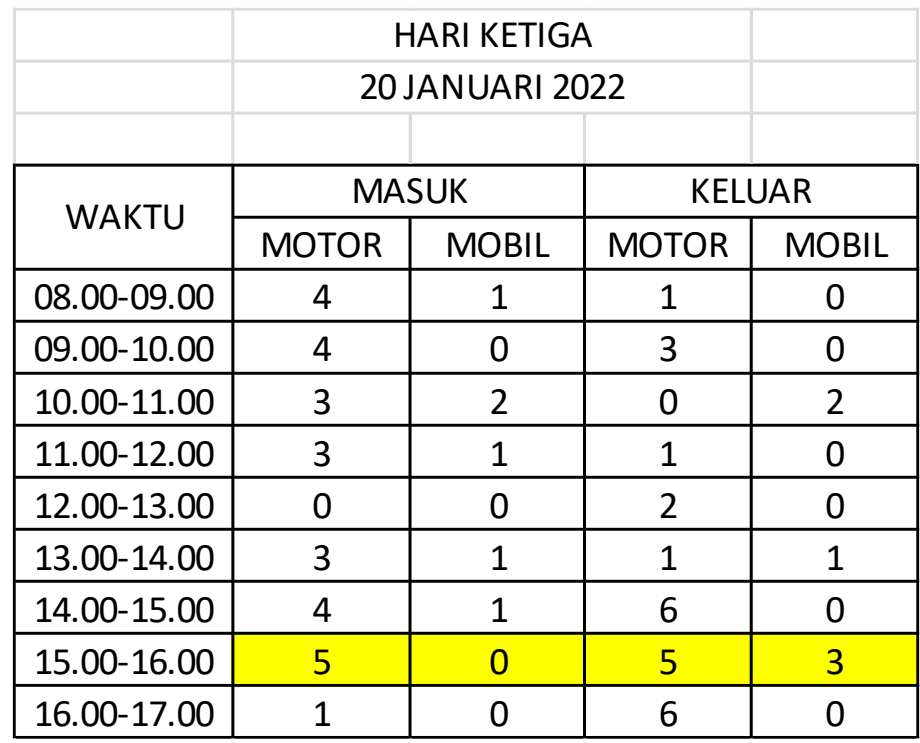

HARI KETIGA

20 JANUARI 2022

\begin{tabular}{|c|c|c|c|c|}
\hline \multirow{2}{*}{ WAKTU } & \multicolumn{2}{|c|}{ MASUK } & \multicolumn{2}{c|}{ KELUAR } \\
\cline { 2 - 5 } & MOTOR & MOBIL & MOTOR & MOBIL \\
\hline $08.00-09.00$ & 4 & 1 & 1 & 0 \\
\hline $09.00-10.00$ & 4 & 0 & 3 & 0 \\
\hline $10.00-11.00$ & 3 & 2 & 0 & 2 \\
\hline $11.00-12.00$ & 3 & 1 & 1 & 0 \\
\hline $12.00-13.00$ & 0 & 0 & 2 & 0 \\
\hline $13.00-14.00$ & 3 & 1 & 1 & 1 \\
\hline $14.00-15.00$ & 4 & 1 & 6 & 0 \\
\hline $15.00-16.00$ & 5 & 0 & 5 & 3 \\
\hline $16.00-17.00$ & 1 & 0 & 6 & 0 \\
\hline
\end{tabular}




\section{BAB IV}

\section{PENUTUP}

\section{A. KESIMPULAN}

- Dari hasil pengamatan survey yang kami lakukan selama 4 hari kerja, kondisi parkir yang berada pada Bank Mega Palopo kondisi parkirnya sudah memenuhi karna area parkirnya kendaraan roda dua dan empat sudah dipisahkan sehingga mempermudah pengunjung dan karyawan juga sudah memiliki tempat parkir tersendiri, keamanannyapun cukup terjmindilihat dari adanya beberapa petugas polisi, satpam,dan beberapa cctv yang terpasang

\section{B. SARAN}

- Mugkin saran dari saya tempat satpamny dan dipintu masuk ATM nya ditambahi kanopi atau sesuatu untuk melindungi terik matahari di sorehari 


\section{DAFTAR PUSTAKA}

Fisu, A. A. (2018). Analisis Lokasi Pada Perencanaan Terminal Topoyo Mamuju Tengah. PENA TEKNIK: Jurnal Ilmiah Ilmu-Ilmu Teknik, 3(1),1-12.

Fisu, A. A. (2019). Tinjauan kecelakaan lalu lintas antar wilayah pada jalan trans provinsi sulawesi selatan. PENA TEKNIK: jurnal ilmiah ilmu-ilmu teknik, 4(1), 53-65.

Abubakar, I. et all, (1998). Pedoman Perencanaan Dan Pengoperasian Fasilitas Parkir, Direktorat Jenderal Perhubungan Darat, Jakarta.

Direktorat Jenderal Perhubungan Darat. (1998). Tentang Pedoman Perencanaan Dan Pengoperasian Fasilitas Parkir. Jakarta.

Kanny, R.A.E.L. (2012). “Analisis Kebutuhan Lahan Parkir Di Rumah Sakit Umum Daerah. Prof. Dr. W.Z. Johannes Kupang”. 1, (4), 88-99

Norasida. (2015). "Evaluasi Kebutuhan Lahan Parkir Pada Pusat Perbelanjaan Di Kota Pontianak (Studi Kasus Swalayan Kaisar)”. Skripsi Fakultas Teknik Untan, Pontianak

Sanyoto, A.J. (2013). "Kajian Area Parkir Off Street Di Surakarta”. Skripsi Fakultas Teknik, Surakarta.

Tamin, O.Z. (2000). Perencanaan \& Pemodelan Transportasi. Institut Teknologi Bandung, Bandung.

Tamin, O.Z. (2003). Perencanaan Permodelan Transportasi Contoh Soal dan Aplikasi Edisi Kesatu, Institut Teknologi Bandung, Bandung.

Wikrama, A.A.J. (2010). “Analisis Karakterisitk Dan Kebutuhan Parkir Di Pasar Kreneng”. 14, (2), 159-170. 